\title{
Urgensi Postmodernisme Terhadap Problematika Dewasa Ini
}

$\begin{array}{ll}\text { Nama } & : \text { Yopi Vredrik Pattipeilohy } \\ \text { Nirm } & : 2020196581 \\ \text { Jurusan } & : \text { Teologi }\end{array}$

Institut Agama Kristen Negeri(IAKN) Toraja

Abstract: The birth of a new understanding, namely postmodernism, one of which is Jean Francouis, is a continuation and criticism of modernism which aims to present an innovation or new thought and solution in his view of science, in terms of postmodernism, science should not be objective but subjective. And an interpretation of man himself, so that truth is relative, therefore postmodernism adds a treasury of knowledge that can be accepted for its existence.

\begin{abstract}
Abstrak : lahirnya suatu paham baru yaitu postmodernisme yang salah satu tokohnya adalah Jean Francouis merupakan kelanjutan dan kritik terhadap modernisme yang bertujuan untuk menghadirkan suatu inovasi atau pemikiran baru dan solusi dalam pandangannya terhadap ilmu pengetahuan, secara pemikiran postmodernisme ilmu pengetahuan seharusnya tidak bersifat objektif melainkan bersifat subjektif dan suatu interpretasi dari manusia itu sendiri, sehingga kebenaran bersifat relatif, maka daripada itu postmodernisme menambahkan pembendaharaan pengetahuan yang dapat diterima keberadaannya.
\end{abstract}




\section{Pendahuluan}

\section{A. Latar Belakang}

Dalam dewasa ini kita kerap kali kita dibelenggu oleh keterikatan struktur dan suatu ajaran resmi yang menjadi culture pada diri sebagian orang dan hal tersebut menjadi suatu hal yang melekat serta membuat kita dibatasi dalam hal berpikir bahkan mengimpelentasikan suatu pendapat, seakan-akan tidak ada ruang lagi bagi kebebasan berpikir atau mengemukakan pendapat, pada saat ini banyak kita dapati suatu perbedaan pendapat yang sebenarnya bisa memberi sumbangsi terhadap sturktur tertentu, tetapi apabila pendapat tersebut melenceng dari ajaran yang telah dibakukan di dalam struktur tersebut, maka pendapat itu akan dianggap menyesatkan tanpa pertimbangan nalar. Dampak dari sikap defensive tersebut tidak akan memberikan suatu perubahan signifikan pada struktur itu sendiri.

\section{B. Tujuan dan manfaat}

Tujuan :Tujuan dari penulisan ini adalah menghadirkan cara berpikir postmodernisme melihat banyaknya keterkakuan ajaran resmi yang ada pada segala struktur tertentu yang kerap kali membuat sebagian orang cenderung dilematis akibat dari ketidakbebasan berpikir serta berpendapat, postmodernisme menyatakan bahwa kebenaran adalah suatu hal yang bersifat relatif maka dari itu segala bangunan atau konstruksi dasar keilmuan yang telah mapan dalam segala bidang seperti sosiologi, psikologi, antorpologi, sejarah, bahkan segala paham yang selama ini baku justru dipertanyakan ulang oleh postmodernisme.

Manfaat : dengan hadirnya cara berpikir postmodernisme maka akan hadir pula ruang kebebasan berpikir, ketidakterikatan oleh sturktur, suatu inovasi pemahaman serta diskursus atau dialektika ilmiah yang penuh dengan pertimbangan nalar yang logis dan perubahan yang signifikan. 


\section{Pembahasan}

Timbulnya postmodernisme tidak dapat dilepaskan dari modernisme itu sendiri. Kata modernisme mengandung makna serba maju, gemerlap, dan progresif. Modernisme ini sangat menjanjikan umat manusia akan suatu relovulis kepada dunia yang lebih mapan di mana semua kebutuhan manusia terpenuh. Rasionalitas akan membantu kita menghadapi suatu mitos-mitos yang disakralkan oleh suatu struktur tertentu dan suatu keyakinan-keyakinan yang sebenarnya tidak mempunyai kebenaran yang mutlak yang pada dasarnya semua itu adalah suatu pembenaran. Munculnya postmodernisme untuk merombak suatu mitos-mitos dan keyakinan tersebut yang membuat manusia tidak berdaya untuk menghadapi suatu problematika yang telah ditawarkan oleh dunia. ${ }^{1}$

Budaya modernisme dan globalisasi membawa berbagai kemudahan bagi umat manusia untuk menyadari tentang apa yang mereka alami selama ini bahwasannya mereka telah dikekang oleh struktur di dalam menggunakan nalar mereka, secara perlahan namun pasti manusia diindoktrinasi oleh lingkungannya untuk menjadi mahluk-mahluk pemburu kesenangan, pada dasarnya doktrinasi seperti ini tidak membawa manusia di dalam ruang lingkup kesenangan tetapi diluar kesadaran manusia tidak menyadari bahwasannya mereka hanya digunakan sebagai media dan tanpa sadar dengan cara ini hanya mendatangkan suatu problematika, sehingga sampai saat ini manusia tidak mendapat suatu inovasi baru di dalam lingkungannya disebabkan manusia tidak ditanamkan didalam pendirian mereka tentang bernalar secara idealisme dikehidupan dewasa ini itu sangatlah perlu untuk melihat lebih jauh tentang permasalahan yang telah terjadi. Realita ini semakin disuburkan oleh membudayanya selera instan, segalanya harus cepat tanpa harus mengajak manusia bernalar untuk mendapatkan suatu inovasi baru.

Tantangan hedonism, modernisme, dan globalisasi, yang semakin kuat mulai melahirkan budaya instan dan mencari jalan pintas. ${ }^{2}$ Timbulnya tantangan-tantangan ini membuat hedonism, modernisme, dan globalisasi perlahan-lahan memudar konflik ini sangat mutlak terjadi di dunia masa kini, dimana kita keluar dari ajaran yang dikatakan budaya instan akan timbulnya suatu asumsi dari manusia bahwasannya hal itu dinilai negatif lalu manusia membuat legitimasi di dalam diri manusia hal seperti

\footnotetext{
${ }^{1}$ Johan Setiawan and Ajat Sudrajat, "Pemikiran Postmodernisme Dan Pandangannya Terhadap Ilmu Pengetahuan," Jurnal Filsafat 28, no. 1 (2018): 25.

2 "4 Jurnal Pascasarjana PAK 2016_DISIPLIN ASKETISME DAN HARMONI," n.d.
} 
ini harus cepat ditindaki atau pengajaran seperti ini cenderung dihindari secara tidak langsung. Manusia masa kini telah diisi dengan asumsi-asumsi yang pada dasarnya tidak relevan yang membuat manusia tidak mendapatkan suatu perkembangan hidup atau suatu inovasi baru di dalam kehidupan manusia dengan akibat doktrinasi ditanamkan di dalam diri mansuia pada masa kini tidak mengajak untuk belajar menggunakan nalar manusia di dalam mengkritik doktrinasi yang tidak relevan untuk diterapkan kepada umat manusia, tetapi pada hakikatnya manusia didoktrinasi untuk satu kata yang harus diprioritaskan untuk diimplementasikan tanpa kesadaran manusia mereka hanya diperalat.

Lahirnya suatu paham baru yang salah satu tokohnya Hans-Georg Gadamer pendalam tentang intuisi sebagai supralogika, dalam hal ini memungkinkan umat manusia bertindak bijak, hidup serasi di dalam dunia. Paham ini tidak jauh beda dengan suatu paham pada postmodernisme yang dimana umat manusia dituntun untuk menggunakan nalar mereka dengan benar berani di dalam mengkritik terhadap doktrinasi yang kemukakan oleh suatu struktur. Olehnya itu intuisi dikatakan supralogika bahwasannya intuisi mengajarkan umat manusia hidup jujur terhadap semua kebenaran tetapi pada dasarnya hanya suatu pembenaran yang tidak ada pembenarannya, intuisi menuntun untuk berpikir secara spesifik terhadap dalam suatu problematika dewasa ini dan olehnya kita dapat mengetahui dan menginterpretasikan tanpa harus dikekang oleh suatu struktur tertentu. ${ }^{3}$

Exemplari, salah satu pembentukan Karakter dan kepribadian seseorang yaitu penelanan berpandangan dengan konsep menyimak/mengamati dan menirukan sebagai salah satu aspek pendidikan agama Kristen. Dan hampir semua ahli pendidikan sepakat bahwa keteladanan dan menirukan adalah alat yang paling ampuh untuk mengajarkan iman secara berulang-ulang. Tanpa kita sadari metode yang seperti ini untuk membentuk karakter dan kepribadian seseorang sangatlah tidak relevan ketika terus menerus diterapkan di dalam ruang lingkun manusia, bahwasannya pembentukan seperti inilah yang membuat manusia tidak menggunakan nalar mereka lagi dan menghidupkan suatu budaya yang instan dimana manusia tidak menggunakan nalarnya dan mengajarkan manusia berpikir secara fundamental tanpa perlunya suatu penjelasan secara spesifik. ${ }^{4}$

\footnotetext{
${ }^{3}$ Rannu Sanderan, "Pendalaman Gagasan Hans-George Gadamer Tentang Intuisi Sebagai Supralogika," jurnal Ilmiah Relogiosity Ettiy Humanity(JIREH) VOL.2 (2020).

4 “3 Jurnal PAK_ganjil 2016_2017_EXEMPLARY,” n.d.
} 
Perlu melihat sosial dan pendidikan melalui budaya yang telah membentuk karakter masyarakat Toraja tradisional bahwasannya pendidikan itu bukanlah suatu intuisi saja atau bukan hanya sekedar latihan intelektual. Pendidikan belum bisa dikatakan pendidikan ketika menghilangkan suatu pembentukan karakter, demikian pembentukan karakter juga sangatlah perlu diterapkan dalam suatu pendidikan untuk membentuk masyarakat Toraja lebih otentik dalam suatu problematika tidak memandang suatu probelmatika dengan sikap acuh tak acuh. Dan juga memberi asumsi kepada masyarakat Toraja bagaimana mereka merawat dengan sempurna kualitas berpikir meraka dengan merawat dengan sempurna kualitas berpikir juga akan menghadirkan suatu kultur yang berinovasi serta menambah martabat dan derajat sebagai masyarakat Toraja Tradisional. ${ }^{5}$

${ }^{5}$ Rannu Sanderan, "Heuristika Dalam Pendidikan Karakter Manusia Toraja Tradisional," BIA': Jurnal Teologi dan Pendidikan Kristen Kontekstual 3, no. 2 (2020): 306-327. 


\section{Kesimpulan}

Perlunya menyadari dalam kehidupan kita dibelenggu dalam suatu struktur yang dimana menawarkan suatu kearifan yang pada dasarnya tidak relevan. Berpikir secara postmodernisme menghantar untuk lebih akurat dalam menggunakan nalar manusia dan dapat membuat suatu asumsi yang kurang konkrit berpikir secara kritik bukan berpikir secara fundamental. Berpikir secara postmodernisme juga menjanjikan kepada umat manusia akan suatu pembaharuan atau inovasi yang mutlak dan membuat umat manusia lebih maju daripada sebelumnya, salah satunya di dalam suatu pendidikan karakter dan kepribadian perlunya diterapkan suatu paham postmodernisme untuk menghantar mereka bagaimana cara berpikir konkrit dan kritik tidak menghantar kepada budaya yang instan tetapi mengajarkan untuk berani menggunakan nalar.

\section{Saran}

Mengemukakakn penerapan cara berpikir postmodernisme dalam menghadapi problematika masa kini untuk menghadirkan suatu inovasi atau pemikiran baru, mengajak umat manusia berani bernalar dan dapat melihat suatu problematika lebih spesifik tidak melihat abstrak, menuntun umat manusia lebih tidak berarah kepada sikap fundamental dan tidak menghidupkan suatu budaya instan.

\section{DAFTAR PUSTAKA}

Rannu Sanderan. "Pendalaman Gagasan Hans-George Gadamer Tentang Intuisi Sebagai Supralogika.” jurnal Ilmiah Relogiosity Ettiy Humanity(JIREH) VOL.2 (2020).

Sanderan, Rannu. "Heuristika Dalam Pendidikan Karakter Manusia Toraja Tradisional." BIA': Jurnal Teologi dan Pendidikan Kristen Kontekstual 3, no. 2 (2020): 306-327.

Setiawan, Johan, and Ajat Sudrajat. "Pemikiran Postmodernisme Dan Pandangannya Terhadap Ilmu Pengetahuan.” Jurnal Filsafat 28, no. 1 (2018): 25.

“3 Jurnal PAK_ganjil 2016_2017_EXEMPLARY,” n.d.

“4 Jurnal Pascasarjana PAK 2016_DISIPLIN ASKETISME DAN HARMONI,” n.d. 